\title{
ANALISIS TINGKAT KEPUASAN PENGGUNA JASA LAYANAN ASRAMA MAHASISWA $X$
}

\author{
Howard S. Giam ${ }^{1)}$, Fahrul Riza ${ }^{2)}$ \\ Fakultas Ilmu Sosial dan Humaniora, Universitas Bunda Mulia \\ emai1 ${ }^{1)}$ : howard giam@bundamulia.ac.id \\ Fakultas Ilmu Sosial dan Humaniora, Universitas Bunda Mulia \\ email ${ }^{2}$ : friza@bundamulia.ac.id
}

\begin{abstract}
The measurement of consumer's satisfaction level can be assigned by comparing the important level of factor with the satisfaction of the attribute. The aim of this study to compare the important and satisfaction of attribute from the tenant's dormitory X. Population of this study are the students who become a tenant of dormitory. Samples of 105 tenants were choosen by non probability sampling technique. Result showed that primary factor in evaluating the service quality are maintain cleanliness at the public space (q1), tables and chairs neatly organized at the public space (q2) and the capability of building management staff keep the good atmosphere for rest and study. These three factor as a primary considerations and being attraction for the tenants.
\end{abstract}

Keywords: Service Quality, Consumer Satisfaction, Importance Factors

\begin{abstract}
Abstrak
Tingkat kepuasan konsumen atas suatu pelayanan dapat diukur dengan membandingkan antara tingkat kepentingan dari kualitas layanan terhadap tingkat kepuasannya. Tujuan dari penelitian ini untuk membandingkan tingkat kepentingan dan kepuasan yang dirasakan oleh penghuni asrama mahasiswa X. Populasi pada penelitian ini adalah mahasiswa penyewa asrama $\mathrm{X}$ dengan pemilihan sampel menggunakan non probability sampling sebanyak 105 responden.Hasil penelitian menunjukan yang menjadi hal utama dalam penilaian kualitas layanan adalah ruangan publik yang selalu terjaga kebersihannya (q1), meja dan tempat duduk yang tertata rapi pada ruang publik (q2), dan kemampuan staff manajemen asrama menjaga kenyamanan suasana untuk beristirahat (q14). Tiga hal ini menjadi perhatian utama dan menjadi daya tarik bagi penyewa asrama.
\end{abstract}

Kata Kunci: Kualitas Layanan, Kepuasan Konsumen, Tingkat Kepentingan. 


\section{PENDAHULUAN}

Perkembangan rumah kos di Jakarta dari tahun ke tahun menunjukan peningkatan yang signifikan. Rumah kos dibuat mewah dan eksklusif dengan tujuan untuk memenuhi permintaan dari pasar penyewa. Dari beragam sumber di internet dan koran, saat ini banyak rumah kos yang mengiklankan tempatnya dengan berfokus pada bangunan mewah dan fasilitas yang lengkap serupa dengan fasilitas yang ada pada hotel berbintang. Faktorfaktor tersebut menyebabkan terjadinya persaingan yang ketat pada bisnis jasa rumah kos. Hal ini membuat para pemilik rumah kos bersaing untuk memberikan jasa yang terbaik supaya para penggunanya tidak pindah ke rumah kos yang lain.

Kualitas layanan akan mempengaruhi kepuasan pelanggan, dimana semakin baik kualitas layanan yang diberikan, maka semakin tinggi pula tingkat kepuasan dari pelanggan. Kualitas layanan menghubungkan pandangan dari pelanggan dan penyedia jasa mengenai kualitas pelayanan, serta merupakan dasar yang baik dalam memahami, mengukur dan memperbaiki kualitas layanan.

Keberadaan asrama mahasiswa $\mathrm{X}$ menjawab kebutuhan para orang tua untuk dapat menyediakan asrama yang aman dan nyaman selama menuntut ilmu bagi putra dan putrinya.

Akan tetapi selain dari untuk memenuhi kebutuhan orang tua, para mahasiswa yang menjadi penghuni yang menggunakan jasa secara langsung perlu dijaga tingkat kepuasannya agar betah dan menjadi penghuni yang loyal

Sebaliknya, jika tingkat kualitas layanan rendah akan berakibat pada kepuasan pelanggan rendah. Konsekuensinya intensi untuk menjadi loyal akan menurun. Perpindahan merek atau perilaku pindah merupakan konsep yang bertolak belakang dengan loyalitas pelanggan. Oleh karena itu, penyedia jasa berusaha untuk meningkatkan intensi loyalitas pelanggannya..

Penelitian yang membahas perpindahan pelanggan telah banyak diteliti sebelumnya diberbagai sektor. 
Misalnya di sektor jasa (Bansal, Taylor, \& James, 2005) dan sektor UKM (Haryanto, 2007), serta sektor UKM pada bengkel mobil (Listyarini, Haryanto, \& Siahaan, 2009). Hasil dalam penelitian tersebut termasuk beragam, yang pada intinya bahwa faktor push yang terdiri dari beberapa faktor seperti kualitas layanan, persepsi nilai, komitmen, kepuasan dan lainnya. Beberapa hal tersebut mengindikasikan apabila tingkatnya rendah, maka intensi untuk berpindah akan tinggi. Oleh karena itu, faktor push sebaiknya ditingkatkan.

Penelitian lainnya oleh Bansal et. al. (2005) mengkaji faktor push yang didalamnya terdapat kualitas layanan dan kepuasan berpengaruh pada intensi untuk berpindah.

Disekitar asrama $\mathrm{X}$ juga terdapat berbagai jasa pelayanan rumah kos. Adanya pesaing ini menjadi tuntutan bagi pengelola asrama mahasiswa $\mathrm{X}$ untuk selalu memperhatikan kebutuhan dan keinginan para penyewa dan berusaha memenuhi harapan konsumen dengan cara memberikan pelayanan yang sesuai dengan porsinya dan lebih baik daripada yang dilakukan oleh pesaing.

Penelitian tentang analisis gap pernah dilakukan oleh M. Dimyati (2002) dalam penelitiannya yang berjudul "Analisis Kesenjangan Antara Harapan Dengan Persepsi Atas Kualitas Pendidikan Tinggi: Kasus Di Fakultas Ekonomi Universitas Jember ", selanjutnya penelitian yang dilakukan oleh Ramadania (2002) dalam judul "Kepercayaan dan Komitmen Sebagai Perantara Kunci Membangun Loyalitas: Survei pada nasabah Bank Muamalat Indonesia Surabaya", dengan model analisis merujuk pada yang dikembangkan oleh A. Parasuraman, et al. (1985)

Penelitian yang berkaitan dengan subyek yang sama yaitu rumah kos pernah dilakukan oleh Nelloh dan Liem (2011). Hasil penelitia menunjukan bahwa kualitas layanan berpengaruh signifikan dan positif terhadap kepuasan, serta memiliki pengaruh yang negatif signifikan terhadap keinginan untuk pindah. Namun, kepuasan pelanggan tidak mampu memberikan pengaruh yang signifikan pada intensi untuk berpindah.. 
Tingkat kepuasan konsumen atas suatu pelayanan dapat diukur dengan membandingkan antara harapan konsumen terhadap kualitas layanan yang diinginkannya dengan kenyataan yang diterimanya atau dirasakannya (Kaihatu, 2008) Tujuan dari penelitian ini adalah untuk membandingkan tingkat kepentingan dan kinerja yang dirasakan oleh para penghuni asrama mahasiswa $\mathrm{X}$.

\section{TINJAUAN KEPUSTAKAAN}

Menurut The Enyclopedia American, asrama yang dikenal dengan istilah Dorminotory, adalah berasal dari kata Dormotorius (Latin), yang berarti a sleeping place, dengan pengertian bahwa dormintory merupakan keseluruhan bangunan dalam hubungannya dengan bangunan pendidikan, yang terbagi atas kamar tidur dan meja belajar bagi penghuninya.

Kepuasan penghuni asrama diukur menggunakan Customer Satisfaction Index (CSI) (Aritonang, 2005). Untuk menciptakan nilai kepuasan bagi pelanggan dalam usaha pengendalian kualitas jasa, ada lima dimensi kualitas yang menjadi fokus pada kualitas layanan yaitu tangibles (bukti fisik), reliability (keandalan), responsiveness (daya tanggap), assurance (jaminan), emphaty (empati).

\section{Konsep Kualitas Layanan}

Kualitas layanan merupakan keseluruhan berbagai ciri dan karakteristik dari suatu produk atau jasa dalam hal kemampuannya untuk memenuhi berbagai kebutuhan yang telah ditentukan atau yang bersifat laten (Parasuraman et.al., 1985).

Metode Servqual adalah metode yang sering digunakan untuk mengukur kualitas layanan. Dalam metode servqual terdapat lima dimensi servqual yang paling menentukan kualitas layanan (Parasuraman et all., 1988 dalam Killa, 2011) yaitu:

1. Tangibles: Fasilitas fisik, peralatan dan penampilan personil.

2. Emphaty: Kepedulian dan perhatian perusahaan kepada pelanggan.

3. Responsiveness: Keinginan perusahaan untuk membantu pelanggan dan menjanjikan jasa yang tepat. 
4. Reliability: Kemampuan perusahaan dalam menepati janji dan dapat diandalkan.

5. Assurance: Pengetahuan dan keramah tamahan para personil dan kemampuan mereka menciptakan opini untuk dapat dipercaya pelanggan.

Salah satu metode untuk mengukur kepuasan pelanggan adalah dengan menggunakan Customer Satisfaction Index (CSI) (Aritonang, 2005). Untuk menciptakan kepuasan pelanggan dalam usaha pengendalian kualitas jasa, kelima dimensi tersebut menjadi prioritas perhatian utama.

Kepuasan penghuni asrama diukur menggunakan Customer Satisfaction Index (CSI) (Aritonang, 2005).

\section{Pengukuran dan Penilaian Kualitas Jasa}

Pada dasarnya untuk mengukur kualitas suatu jasa atau produk dapat dilakukan melalui pengukuran atas kepuasan pelanggannya yang ditunjukkan melalui variabel harapan dan kinerja yang dirasakan pelanggan atau perceived performance. (Fandy Tjiptono,
2001:46). Selanjutnya Kotler (1997: 95) menjelaskan bahwa jasa dapat diperingkat menurut kepentingan pelanggan (costumer importance) dan kinerja perusahan (company performance). "Akan tetapi kualitas jasa lebih sukar didefinisikan, dijabarkan, dan diukur bila dibandingkan dengan kualitas barang. Bila ukuran kualitas dan pengendalian telah lama ada untuk barang barang berwujud (tangible goods), maka untuk jasa berbagai upaya telah dan sedang dikembangkan untuk merumuskan ukuran-ukuran semacam itu" (Fandy Tjiptono, 2000:51). Kemudian Parasuraman, et al., (1988:12) mendefinisikan penilaian kualitas jasa sebagai sikap yang berhubungan dengan keunggulan suatu jasa pelayanan, atau pertimbangan konsumen tentang keunggulan secara keseluruhan suatu perusahaan. Demikian pula Wyckof yang melihat keunggulan jasa pelayanan sebagai suatu tingkat kesempurnaan yang diharapkan dan pengendalian atas kesempurnaan tersebut untuk memenuhi seperangkat keinginan dan kebutuhan pelanggan (Wyckof, dalam Lovelock, 1988:45). 
Dari uraian diatas dapat diketahui bahwa pengukuran dan penilaian kualitas jasa tidaklah berbeda, namun dalam pelaksanaannya agak sukar dibandingkan pada produk fisik. Pada dasarnya inti dari pengukuran dan penilaian kualitas terletak pada dua sisi, yaitu dari sudut pandang konsumen dalam hal ini harapannya, dan disatu sisi terletak pada sudut pandang manajemen perusahaan. yaitu kinerja atas kualitas jasa secara keseluruhan.

Seperti yang dikemukakan oleh Parasuraman, et al. (1985:43) bahwa terdapat dua faktor utama yang mempengaruhi kualitas jasa, yaitu; jasa yang diharapkan (expected service) dan jasa yang dipersepsikan (perceived service). Sejalan dengan pendapat tersebut, menurut Rush, et al. (1996) dalam Fandy Tjiptono, (2000:51-52) bahwa: "Harapan pelanggan dapat berupa tiga tipe. Pertama, will expectation, yaitu tingkat kinerja yang diprediksi atau diperkirakan konsumen akan diterimanya, berdasarkan semua informasi yang diketahuinya. Kedua, harapan seharusnya, yaitu tingkat kinerja yang dianggap sudah sepantasnya diterima konsumen. Ketiga, harapan ideal, yaitu kinerja optimum atau terbaik yang diharapkan dapat diterima konsumen". Hal yang sama juga dikemukakan oleh Gronroos (1990) dalam Fandy Tjiptono, (2000:51-52) menyatakan bahwa persepsi pelanggan terhadap kualitas total suatu jasa terdiri atas dua dimensi utama. Dimensi pertama, yakni kualitas teknik (outcome dimension) yang berkaitan dengan kualitas output jasa yang dipersepsikan pelanggan. Dan dimensi kedua, yaitu kualitas fungsi (process-related dimension) berkaitan dengan kualitas cara penyampaian jasa atau menyangkut proses transfer kualitas teknis, output atau hasil akhir jasa dari penyedia jasa kepada pelanggan. Untuk jelasnya dapat ditunjukkan pada Gambar 1. 
Gambar 1. Total Perceived Quality
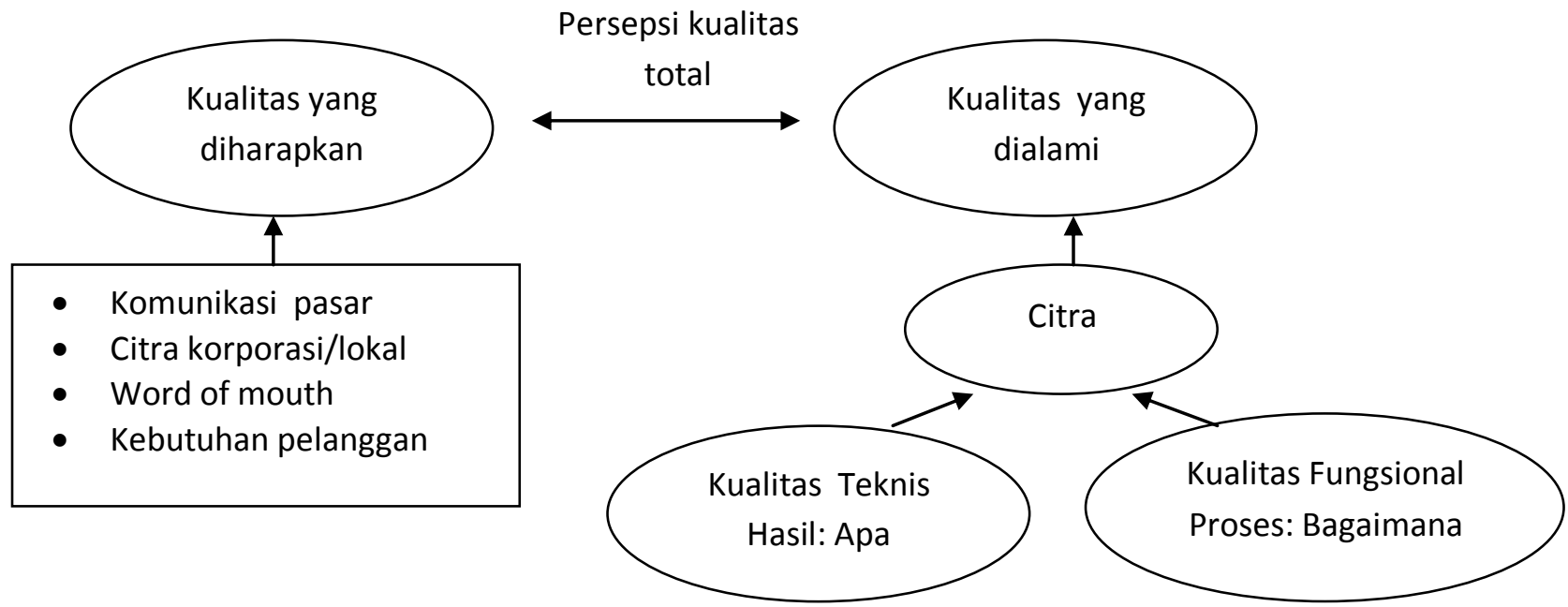

Sumber:: Gronroos (1990) dalam Fandy Tjiptono (2000).

Dalam banyak kasus, pelanggan dapat melihat dan mengetahui perusahaan, sumber daya, dan cara beroperasinya. Sebab itu, citra korporasi dan atau lokal (corporate and/or local image) merupakan faktor utama dalam industri jasa. Faktor tersebut dapat mempengaruhi persepsi terhadap kualitas melalui berbagai cara. Jika penyedia jasa memiliki citra positif di dalam benak pelanggan, kesalahan minor yang terjadi sangat mungkin dimaafkan. Apabila kesalahan kerap terjadi, maka citra positif tersebut akan rusak. Sebaliknya, jika citra organisasi sudah negatif terlebih dahulu, maka pengaruh atau efek dari setiap kesalahan yang dilakukannya kerapkali jauh lebih besar daripada bila citranya positif. Dalam kaitannya dengan persepsi terhadap kualitas, citra dapat dipandang sebagai filter (Fandy Tjiptono, 2000:51-52).

\section{Kepuasan Konsumen}

Kepuasan merupakan tingkat perasaan konsumen setelah membandingkan antara kinerja layanan yang diterimanya dengan kinerja layanan yang diharapkannya antara harapan dengan kinerja layanan. Apabila kinerja layanan di bawah harapan, maka konsumen akan kecewa. Bila kinerja layanan sesuai dengan harapan, maka konsumen akan merasa puas. Patut diingat pula bahwa layanan yang memuaskan merupakan bagian masa depan perusahaan (Budiono, 1996:4).. Ini berarti bahwa tingkat kepuasan merupakan fungsi dari 
perbedaan kelima kesenjangan yang dikutip oleh Fandy Tjiptono, 2001:46-48) yaitu:

1. Kesenjangan antara harapan konsumen dan persepsi manajemen Manajemen tidak selalu dapat merasakan apa yang diinginkan oleh para pelanggan secara tepat.

2. Kesenjangan antara persepsi manajemen dan spesifikasi kualitas jasa Mungkin manajemen mampu merasakan secara tepat apa yang diinginkan oleh para pelanggan, namun tidak menyusun suatu standar kinerja tertentu.

3. Kesenjangan antara spesifikasi jasa dan penyampaian jasa Karyawan perusahan mungkin kurang dilatih atau bekerja melampaui batas dan tidak dapat dan tidak mampu untuk memenuhi standar.

4. Kesenjangan antara penyampaian jasa dan komunikasi eksternal Harapan konsumen dipengaruhi oleh pernyataan pernyataan yang dibuat oleh wakil (representatives) dan iklan perusahaan.

5. Kesenjangan antara jasa yang dirasakan dan jasa yang diharapkan.

\section{METODE PENELITIAN}

Untuk menciptakan nilai kepuasan bagi pelanggan dalam usaha pengendalian kualitas jasa, ada lima dimensi kualitas yang menjadi fokus pada kualitas layanan yaitu tangibles (bukti fisik), reliability (keandalan), responsiveness (daya tanggap), assurance (jaminan), emphaty (empati).

\section{Jenis Penelitian, Populasi dan Sampel}

Pendekatan penelitian ini adalah pendekatan kuantitatif yang bertujuan untuk mengukur tingkat kesenjangan (gap) antara harapan yang dengan kenyataan dalam hal ini adalah kualitas layanan. Penelitian ini termasuk pada jenis penelitian deskriptif karena digunakan untuk mengembangkan model penelitian yang bertujuan untuk mengukur kesenjangan antara harapan konsumen dengan kinerja perusahaan.

Populasi penelitian ini adalah mahasiswa penyewa asrama $\mathrm{X}$. 
Pemilihan sampel dengan menggunakan non probability sampling yaitu pemilihan sampel berdasarkan pada pertimbangan pribadi (Supramono \& Haryanto, 2005). Berdasarkan penjelasan tersebut maka penelitian ini menggunakan non probability sampling dengan jenis purposive sampling yaitu peneliti memilih sampel berdasarkan kriteria tertentu untuk memilih sampel yang diharapkan memiliki informasi yang akurat (Supramono \& Haryanto, 2005). Syarat utama untuk dapat menjadi responden adalah telah tinggal minimal 6 bulan berturutturut.

\section{Jenis dan Sumber Data}

Penelitian ini menggunakan data yang bersumber dari

1. Data primer, yaitu data yang diperoleh melalui penyebaran kuesioner yang terbatas pada mahasiswa pengguna asrama mahasiswa $X$ dan sudah menempati asrama tersebut selama minimal 6 bulan. Pengambilan data dilakukan secara langsung kepada mahasiswa penyewa asrama dengan meminta kesediaannya utuk mengisi kuesioner.

2. Data Sekunder, merupakan data yang diperoleh dari tinjauan kepustakaan melalui literatur, jurnal-jurnal, dan situs internet yang dapat memberikan informasi yang berkaitan dengan kualitas layanan, dan analisis kesenjangan yang sesuai dengan masalah penelitian.

\section{Definisi Operasional Variabel}

Kualitas layanan yaitu keseluruhan berbagai ciri dan karakteristik dari sebuah asrama yang terkait dengan bagaimana kemampuan produk atau jasa untuk memenuhi berbagai kebutuhan yang telah ditentukan atau yang bersifat laten.

Indikator empirik dari penelitian ini disajikan pada tabel 1 berikut

Tabel 1. Indikator Empirik

\begin{tabular}{|l|l|}
\hline q1 & $\begin{array}{l}\text { Ruangan publik pada asrama } \\
\text { terjaga kebersihannya }\end{array}$ \\
\hline q2 & $\begin{array}{l}\text { Meja dan tempat duduk pada } \\
\text { ruang publik tertata dengan } \\
\text { rapi }\end{array}$ \\
\hline q3 & $\begin{array}{l}\text { Adanya shuttle bus } \\
\text { menghemat waktu ke kampus }\end{array}$ \\
\hline q4 & Lift cepat diakses \\
\hline q5 & $\begin{array}{l}\text { Lokasi asrama mudah } \\
\text { dijangkau oleh angkutan } \\
\text { umum }\end{array}$ \\
\hline q6 & Dekat ATM, Minimart, \\
\hline
\end{tabular}




\begin{tabular}{|l|l|}
\hline & Restoran \\
\hline $\mathrm{q} 7$ & $\begin{array}{l}\text { Pendingin ruangan berfungsi } \\
\text { dengan baik }\end{array}$ \\
\hline $\mathrm{q} 8$ & $\begin{array}{l}\text { Parkir kendaraan selalu } \\
\text { tersedia }\end{array}$ \\
\hline $\mathrm{q} 9$ & $\begin{array}{l}\text { Lobby untuk kemudahan } \\
\text { menerima tamu }\end{array}$ \\
\hline $\mathrm{q} 10$ & $\begin{array}{l}\text { Student lounge untuk tempat } \\
\text { belajar dapat dimanfaatkan } \\
\text { dengan baik }\end{array}$ \\
\hline $\mathrm{q} 11$ & $\begin{array}{l}\text { Laundry untuk jasa cuci } \\
\text { pakaian }\end{array}$ \\
\hline $\mathrm{q} 12$ & $\begin{array}{l}\text { Banyak pilihan makanan pada } \\
\text { kantin }\end{array}$ \\
\hline $\mathrm{q} 13$ & $\begin{array}{l}\text { Harga sewa kamar yang } \\
\text { diberikan sesuai dengan } \\
\text { mahasiswa }\end{array}$ \\
\hline $\mathrm{q} 14$ & $\begin{array}{l}\text { Manajemen gedung } \\
\text { memelihara kenyamanan } \\
\text { suasana untuk istirahat }\end{array}$ \\
\hline $\mathrm{q} 15$ & $\begin{array}{l}\text { Manajemen gedung menjaga } \\
\text { ketenangan suasana untuk } \\
\text { belajar }\end{array}$ \\
\hline $\mathrm{q} 16$ & $\begin{array}{l}\text { Manajemen gedung menjaga } \\
\text { keamana lingkungan dengan } \\
\text { baik }\end{array}$ \\
\hline $\mathrm{q} 17$ & $\begin{array}{l}\text { Manajemen gedug melakukan } \\
\text { perawatan berkala terhadap } \\
\text { fasilitas asrama }\end{array}$ \\
\hline $\mathrm{q} 18$ & $\begin{array}{l}\text { Cepat dalam memperpaiki } \\
\text { kerusakan fasilitas }\end{array}$ \\
\hline $\mathrm{q} 19$ & $\begin{array}{l}\text { Cepat tanggap dalam } \\
\text { menangani keluhan }\end{array}$ \\
\hline
\end{tabular}

\section{TEKNIK ANALISIS DATA}

\section{Statistik Deskriptif}

Dalam penelitian ini penulis melakukan perhitungan distribusi frekuensi dan mean (nilai rata-rata) untuk memberikan gambaran atau deskripsi dari data yang diperoleh.

\section{Analisa Kepentingan Konsumen-}

\section{Kinerja Perusahaan}

Kotler (1997:95) berpendapat bahwa jasa dapat diperingkat menurut kepentingan pelanggan (Customer Importance) dan kinerja perusahaan (Company Performance). Kepentingan diperingkat dengan skala empat titik, seperti; sangat penting, penting, kurang penting, dan tidak penting. Sedangkan kinerja juga diperingkat dengan skala empat titik, seperti: sangat baik, baik, kurang baik, dan tidak baik. Dalam pelaksanaan penelitian, metode ini akan digunakan untuk menganalisis secara deskriptif kualitas jasa, dilihat berdasarkan tingkat kesesuaian antara jasa yang diharapakan (kepentingan konsumen) dengan jasa yang dirasakan (kinerja perusahaan). Tingkat kesesuaian yang dimaksud dalam pelaksanan penelitian adalah hasil perbandingan skor nilai jasa yang diharapkan (kepentingan konsumen) dengan skor nilai jasa yang dirasakan (kinerja perusahaan).

Rumus yang digunakan untuk penilaian tingkat kesesuaian adalah:

$$
T K i=\frac{X i}{Y i} x 100
$$

- TKi :Tingkat kesesuaian 
- Xi : Skor penilaian jasa yang dirasakan

- Yi : Skor penilaian jasa yang diharapkan

Untuk sumbu mendatar (X) merupakan skor untuk jasa yang dirasakan, sedangkan untuk sumbu tegak (Y) merupakan skor untuk jasa yang diharapkan. Skor-skor penilaian tersebut akan disederhanakan untuk mendapatkan nilai rata-rata masingmasing faktor. Penyederhanaan masing-masing faktor penilaian tersebut dengan menggunakan formula sebagai berikut:

$$
\bar{X}=\frac{\sum X i}{n} \quad \bar{Y}=\frac{\sum Y i}{n}
$$

Keterangan:

- $\mathrm{Xi}=$ Skor penilaian jasa yang dirasakan

- $\mathrm{Yi}=$ Skor penilaian jasa yang diharapankan

- $\mathrm{X}=$ Skor rata-rata penilaian jasa yang dirasakan

- $\mathrm{Y}=$ Skor rata-rata penilaian jasa yang diharapkan

- $\mathrm{n}=$ Jumlah sampel

Diagram kartesius merupakan suatu bangun yang dibagi atas empat bagian yang dibatasi oleh dua buah baris yang berpotongan pada titiktitik $(\mathrm{X}, \mathrm{Y})$. Untuk $\mathrm{X}$ adalah rata-rata dari rata-rata skor jasa yang dirasakan, dan $\mathrm{Y}$ adalah rata-rata dari rata-rata skor jasa yang diharapkan. Untuk jelasnya rumus yang dimaksud adalah:

$$
\overline{\bar{X}}=\frac{\sum N_{i-i} \bar{X}}{K} \quad \overline{\bar{Y}}=\frac{\sum N_{i-i} \bar{Y}}{K}
$$

Keterangan:

$X=$ Skor rata-rata penilaian jasa yang dirasakan

$Y=$ Skor rata-rata penilaian jasa yang diharapkan

$\mathrm{X}=$ Rata-rata skor rata-rata penilaian jasa yangdirasakan

$Y=$ Rata-rata skor rata-rata penilaian jasa yang diharapkan $\mathrm{K}$ = Banyaknya faktor

Masing-masing dimensi penilaian baik skor ratarata penilaian jasa yang dirasakan $(\mathrm{X})$ maupun skor rata-rata penilaian jasa yang diharapkan (Y) dijabarkan ke dalam empat bagian Diagram Kartesius. 


\begin{tabular}{|l|l|}
\hline & \\
$\begin{array}{l}\text { 2. Prioritas } \\
\text { Utama/Konsentrasi }\end{array}$ & $\begin{array}{l}\text { 1. Prestasi yang baik } \\
\text { (pertahankan) }\end{array}$ \\
& \\
\hline 3.Prioritas Rendah & 4. Berlebihan \\
\hline
\end{tabular}

Gambar 2. Diagram Kartesius Analisa Kepentingan-Kinerja

\section{ANALISIS DAN PEMBAHASAN}

Dari kuesioner yang disebarkan sebanyak 150 kuesioner, total kuesioner yang lengkap terisi sebanyak 105 kuesioner. Berikut ini dipaparkan analisis secara deskriptif

\section{Alasan Memilih Asrama X}

Grafik 1 menggambarkan proporsi penyewa berdasarkan alasan memilih asrama mahasiswa $\mathrm{X}$ sebagai tempat tinggal selama kuliah. Alasan terbesar adalah karena lokasi asrama yang dekat dengan kampus, pilihan kedua adalah karena tampilan gedung yang terlihat mewah.

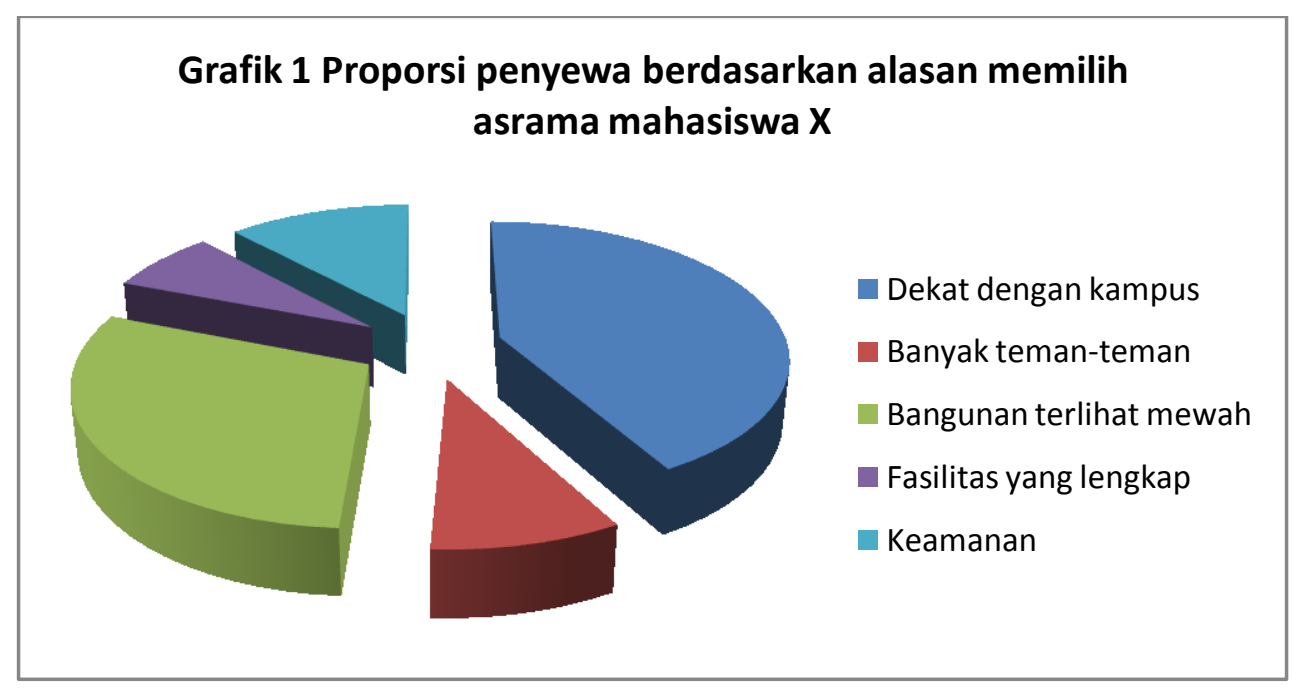


Analisis Tingkat Kepentingan dan

\section{Kepuasan}

Untuk melihat bagaimana kondisi kualitas layanan dan kualitas produk, hasil perhitungan disajikan pada tabel berikut.

antara harapan dan kenyataan dari

Tabel 2. Total Rata-Rata Tanggapan Responden Terhadap Jasa yang Diharapkan

dengan Jasa yangDirasakan

\begin{tabular}{|c|c|c|c|c|c|}
\hline Variabel & Faktor & & Nilai & & Hipotesis (df \\
\hline & & Kepentingan & Kepuasan & Gap & \\
\hline $\mathrm{q} 1$ & $\begin{array}{l}\text { Ruangan publik pada asrama } \\
\text { terjaga kebersihannya }\end{array}$ & 3.56190 & 3.3524 & -0.20952 & H0 Accepted \\
\hline $\mathrm{q} 2$ & $\begin{array}{l}\text { Meja dan tempat duduk pada } \\
\text { ruang publik umum pada } \\
\text { asrama tertata dengan rapi }\end{array}$ & 3.51429 & 3.3905 & -0.12381 & H0 Accepted \\
\hline q3 & $\begin{array}{l}\text { Adanya shuttle bus menghemat } \\
\text { waktu ke kampus }\end{array}$ & 4.62857 & 4.1048 & -0.52381 & H1 Accepted \\
\hline q4 & Lift cepat diakses & 4.55238 & 4.2190 & -0.33333 & H1 Accepted \\
\hline q5 & $\begin{array}{l}\text { Lokasi asrama mudah } \\
\text { dijangkau oleh angkutan umum }\end{array}$ & 4.03810 & 3.2381 & -0.8 & H1 Accepted \\
\hline q6 & $\begin{array}{l}\text { Dekat ATM, Minimart, } \\
\text { Restoran }\end{array}$ & 4.34286 & 3.1714 & -1.17143 & H1 Accepted \\
\hline q7 & $\begin{array}{l}\text { Pendingin ruangan berfungsi } \\
\text { dengan baik }\end{array}$ & 4.57143 & 3.8190 & -0.75238 & H1 Accepted \\
\hline $\mathrm{q} 8$ & Parkir kendaraan selalu tersedia & 4.57143 & 3.4857 & -1.08571 & H1 Accepted \\
\hline q9 & $\begin{array}{l}\text { Lobi untuk kemudahan } \\
\text { menerima tamu }\end{array}$ & 4.29524 & 3.3524 & -0.94286 & H1 Accepted \\
\hline q10 & $\begin{array}{l}\text { Student lounge nyaman } \\
\text { digunakan untuk tempat belajar }\end{array}$ & 4.32381 & 3.4286 & -0.89524 & H1 Accepted \\
\hline q11 & $\begin{array}{l}\text { Laundry untuk jasa cuci } \\
\text { pakaian }\end{array}$ & 4.45714 & 3.1714 & -1.28571 & H1 Accepted \\
\hline q12 & $\begin{array}{l}\text { Banyak pilihan variasi makanan } \\
\text { pada kantin }\end{array}$ & 3.10476 & 2.2476 & -0.85714 & H1 Accepted \\
\hline q13 & $\begin{array}{l}\text { Harga yang diberikan sesuai } \\
\text { dengan mahasiswa }\end{array}$ & 3.73333 & 2.9238 & -0.80952 & H1 Accepted \\
\hline q14 & $\begin{array}{l}\text { Manajemen gedung memelihara } \\
\text { kenyamanan suasana untuk } \\
\text { istirahat }\end{array}$ & 4.08571 & 3.3810 & -0.70476 & H1 Accepted \\
\hline
\end{tabular}




\begin{tabular}{|l|l|l|l|l|l|}
$\mathrm{q} 15$ & $\begin{array}{l}\text { Manajemen gedung menjaga } \\
\text { ketenangan suasana untuk } \\
\text { belajar }\end{array}$ & 4.14286 & 3.2667 & -0.87619 & H1 Accepted \\
\hline q16 & $\begin{array}{l}\text { Manajemen gedung menjaga } \\
\text { keamana lingkungan dengan } \\
\text { baik }\end{array}$ & 4.37143 & 3.7619 & -0.60952 & H1 Accepted \\
\hline q17 & $\begin{array}{l}\text { Manajemen gedug melakukan } \\
\text { perawatan berkala terhadap } \\
\text { fasilitas asrama }\end{array}$ & 4.17143 & 3.1333 & -1.0381 & H1 Accepted \\
\hline q18 & $\begin{array}{l}\text { Cepat dalam memperpaiki } \\
\text { kerusakan fasilitas }\end{array}$ & 4.51429 & 3.0190 & -1.49524 & H1 Accepted \\
\hline q19 & $\begin{array}{l}\text { Cepat tanggap dalam } \\
\text { menangani keluhan }\end{array}$ & 4.58095 & 2.8000 & -1.78095 & H1 Accepted \\
\hline & & $\mathbf{4 . 2 2 8 5 7}$ & $\mathbf{3 . 3 2 9 8 2 4 6}$ & & \\
\hline
\end{tabular}

Sumber: Hasil survey,. Data diolah

Hasil analisis menunjukan bahwa rata-rata nilai kenyataan yang dirasakan masih dibawah harapan. Secara menyeluruh tingkat penilaian dari para penyewa asrama terhadap kualitas layanan yang diberikan berada pada angka 3,32, yaitu pada level cukup puas.

Tingkat harapan tertinggi adalah pada kecepatan dalam menanggapi keluhan (S7) dengan nilai harapan adalah 4,228, namun dalam kenyataannya nilai kenyataan yang dirasakan adalah 3,329, cepat menanggapi keluhan merupakan kualitas layanan yang terbesar kesenjangaannya.

Untuk indikator yang paling rendah kesenjangannya adalah meja dan tempat duduk pada asrama yang tertata rapi dengan nilai harapan
3,514 dan kinerja yang dirasakan dengan nilai 3,39 dengan nilai kesenjangan $-0,2381$.

Untuk mengetahui apakah terdapat perbedaan antara harapan dengan kenyataan, maka selanjutnya dilakukan uji $\mathrm{T}$ terhadap masingmasing indikator. Hasil pengujian dengan uji $\mathrm{T}$ menunjukan dengan derajat kepercayaan 95\% ditemukan bahwa bahwa

1. H0 diterima untuk Ruangan publik pada asrama terjaga kebersihannya

2. H0 diterima untuk Meja dan tempat duduk pada ruang publik umum pada asrama tertata dengan rapi

Artinya adalah para penyewa tidak merasakan perbedaan yang 
signifikan antara harapan nya dengan kenyataan yang dialaminya.

Namun untuk indikator lainnya dari q3 sampai dengan q19 hasil pengujian dengan menggunakan uji $\mathrm{T}$ dengan derajat kepercayaan 95\% menunjukan perbedaan yang signifikan antara harapan dengan kenyataan. Dari nilai gap yang dihasilkan menunjukan nilai minus, hal itu berarti bahwa kinerja manajemen gedung pada masa periode penelitian masih berada dibawah harapan dari para penyewa asrama.

Gambar 2. Diagram Kartesius Dimensi Kepentingan dan Kepuasan yang Dirasakan Penyewa Asrama

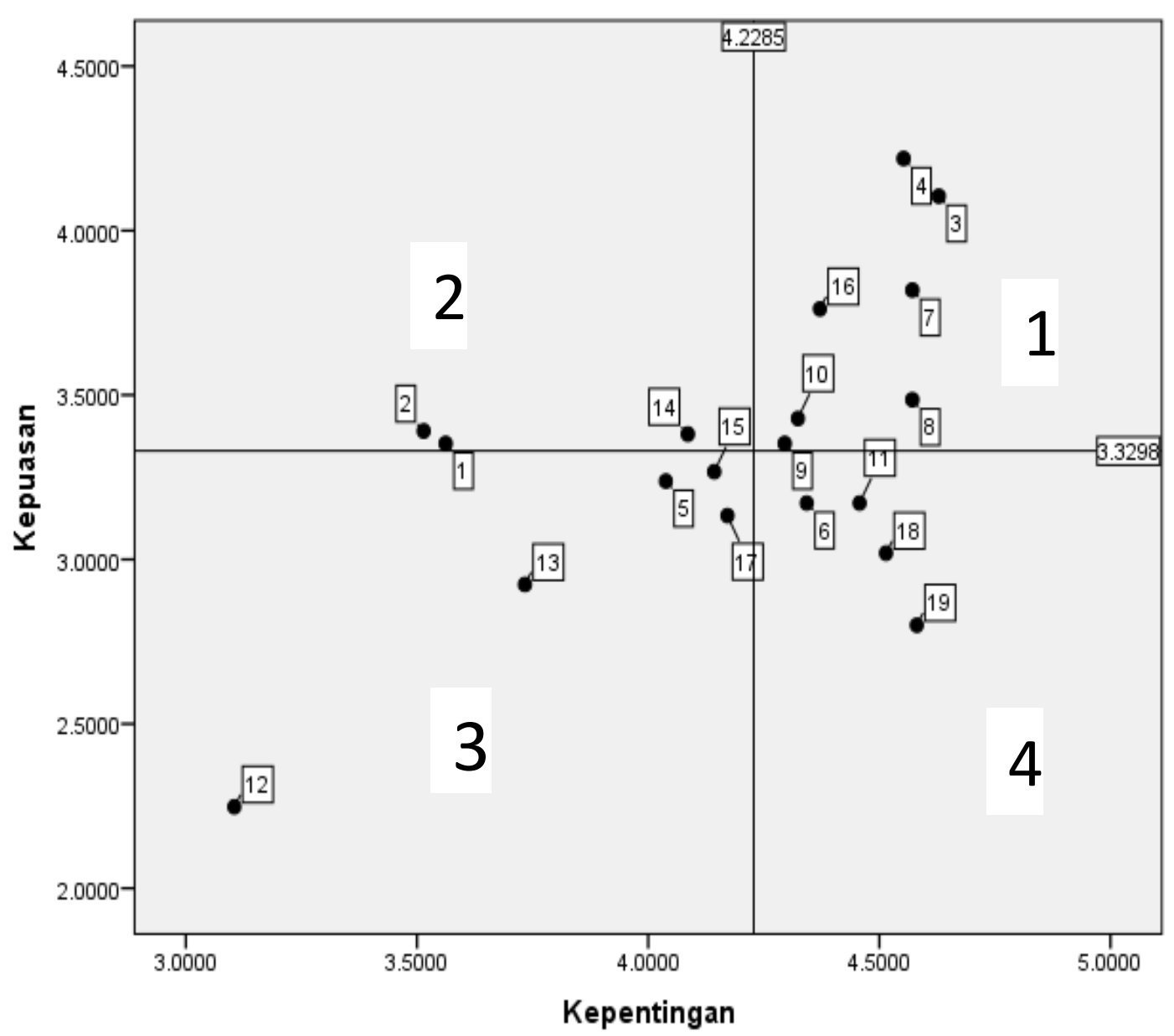


Hasil perhitungan dengan menggunakan diagram kartesius menunjukan adanya shuttle bus menuju kampus (q3), kemudahan dalam menggunakan lift (q4), pendingin ruangan berfungsi dengan baik (q7), tempat parkir kendaraan yang selalu tersedia (q8), kenyamann lobby sebagai tempat menerima tamu (q9), student lounge untuk tempat belajar dapat dimanfaatkan dengan baik (q10), merupakan prestasi yang baik dan harus dipertahankan.

Hal berikutnya yang menjadi prioritas utama adalah ruangan publik yang selalu terjaga kebersihannya (q1), meja dan tempat duduk yang tertata rapi pada ruang public (q2), dan manajemen gedung menjaga kenyamanan suasana untuk beristirahat (q14). Tiga hal ini menjadi fokus utama dan menjadi daya tarik bagi penyewa asrama.

Dari matrik dapat juga dilihat bahwa fasilitas dekat dengan ATM (6) laundry (11), penangan kerusakan pada ruang publik $(\mathrm{q} 18, \mathrm{q} 19)$ memberikan tingkat kepuasan yang rendah bagi para penyewa, padahal dalam harapan penyewa indikator ini memiliki tingkat kepentingan yang tinggi. Untuk lokasi asrama yang mudah dijangkau oleh angkutan umum (q5), harga yang dikenakan (q13), variasi makanan pada kantin (q12), manajemen gedung menjaga ketenangan suasana belajar (q15) dan manajemen gedung melakukan servis berkala terhadap fasilitas asrama (q17), merupakan hal yang memiliki tingkat kepentingan rendah bagi penyewa dan kinerja yang dirasakan juga rendah.

\section{Pembahasan}

Tingkat kepuasan seorang konsumen atas suatu pelayanan yang telah diterima, dapat diukur dengan membandingkan setiap kepentingan (harapan) yang diyakini dengan kinerja yang dirasakan. Bila seorang konsumen mengharapkan suatu pelayanan pada tingkat tertentu, dan yang dirasakan adalah bahwa pelayanan yang diterima lebih tinggi dari apa yang diharapkan, maka konsumen tersebut dapat dikatakan sangat puas. Demikian pula apabila konsumen mengharapkan suatu tingkat pelayanan tertentu, dan pada kenyataannya konsumen tersebut merasakan bahwa pelayanan yang diterimanya sesuai dengan harapannya, maka konsumen tersebut dapatlah dikatakan puas. Sebaliknya, bila kinerja yang dirasakannya lebih rendah dari kualitas layanan yang diharapkannya, maka konsumen tersebut akan dikatakan sebagai 
konsumen yang tidak puas atau kecewa.

Pengelola asrama (manajemen gedung) harus dapat memberikan jasa pelayanan yang bermutu dan lebih baik daripada pesaingnya. Penyewa pada dasarnya harus dipuaskan dengan total nilai yang tinggi, bila tidak maka penyewa dapat dengan mudah berpindah ke tempat lain. Karena saat ini penyewa dapat dengan mudah berpindah dari satu tempat ke tempat lainnya, yang dapat memberikan kepuasan sesuai dengan tingkat pelayanan yang diinginkannya.

Adalah sesuatu yang sulit bagi seseorang untuk memilih di antara sekian banyak produk (beraneka ragam), yang dapat dijadikan sebagai alat pemuas kebutuhan dan keinginan. Konsumen dihadapkan dengan berbagai pilihan yang merupakan perangkat pilihan produk/perangkat kebutuhan. Nilai kepuasan adalah suatu konsep yang dapat memandu dan memudahkan konsumen, di dalam memilih diantara berbagai alternatif perangkat kebutuhan atau perangkat variasi pilihan produk (Kotler,1997:16).

Pandangan Kotler tersebut kemudian diperkuat lagi oleh pendapat Massie: Apalagi dewasa ini semakin banyak pilihan produk dan jasa yang sama ditawarkan pesaing. Disadari atau tidak, saat ini pelanggan memiliki daya tawar yang semakin kuat. Produk satu-satunya yang dicari adalah produk yang memberikan total nilai yang tinggi dan mampu memberikan kepuasan sesuai harapan pelanggan atau jauh melebihi apa yang diharapkan. Bilamana semua ini mampu disediakan perusahaan, maka diharapkan pelanggan akan tetap loyal dengan perusahaan. (Massie, 1998:2).

Kuadran 1 merupakan indikatorindikator yang dirasakan oleh penyewa memiliki tingkat kepentingan yang tinggi untuk dipenuhi dan dalam hal ini pengelola asrama telah berhasil memberikan layanan yang memuaskan. Indikator-indikator yang masuk pada kuadran 1 ini tidak dapat berkurang dan harus tetap dipertahankan. Kelalaian dalam mempertahankan kualitas layanan pada kuadran 1 akan mengakibatkan tingkat kepuasan penyewa akan menurun.

Kuadran 2, merupakan indikator yang dianggap oleh penyewa bukan merupakan hal yang penting namun memberikan tingkat kepuasan yang tinggi. Indikator-indikator pada kuadran ini walaupun bukan merupakan hal yang penting bagi penyewa, namun karena sudah memberikan kepuasan yang tinggi 
maka kinerjanya tetap harus dipertahankan.

Kuadran 3, merupakan indikator yang dianggap oleh penyewa bukan merupakan hal yang penting dan kinerja yang dirasakan rendah. Peningkatan kualitas layanan pada indikator-indikator ini tidak akan meningkatkan perasaan kepuasan secara signifikan. Namun pengelola asrama tetap harus berusaha untuk menaikan kualitas layanannya agar berada pada kuadran 2. Karena bagaimanapun seorang konsumen mengharapkan apa yang diterimanya lebih dibanding apa yang dibayarkannya.

Fokus utama peningkatan nilai kepuasan adalah pada indikatorindikator yang berada pada kuadran 4 dimana pada kuadran ini, indikatorindikator tersebut memiliki tingkat kepentingan yang tinggi namun kepuasan yang dirasakan masih rendah. Merupakan pekerjaan utama bagi pengelola asrama untuk memindahkan indikator-indikator yang berada pada kuadran 4 ini ke kuadran 1.

\section{PENUTUP}

Alasan terbanyak para penyewa untuk tinggal di asrama $\mathrm{X}$ adalah karena lokasi dekat dengan lokasi kampus. Pertimbangan lokasi ini

menjadi prioritas utama mengingat padatnya situasi jalan di wilayah Jakarta. Pihak pengelola asrama harus mampu menekankan keunggulan faktor kedekatan dengan kampus ini untuk menarik minat penyewa baru.

Fasilitas shuttle bus menuju kampus, kecepatan dalam mendapatkan lift untuk naik dan turun, pendingin ruangan berfungsi dengan baik, tempat parkir kendaraan yang selalu tersedia, kenyamann lobby sebagai tempat menerima tamu, student lounge untuk tempat belajar dapat dimanfaatkan dengan baik, merupakan prestasi yang baik dan harus dipertahankan bahkan ditingkatkan, untuk memberikan kualitas layanan yang prima kepada penyewa.

Ketersediaan mesin anjungan tunai mandiri, jasa laundry dan penangangan kerusakan pada ruang publik memberikan nilai kepuasan yang rendah. Padahan penilaian dari para penyewa terhadap kepentingan dari indikator ini tinggi. Kuadran 4 menjadi prioritas utama bagi pengelola asrama untuk segera dilakukan perbaikann.

Kuadran 2, menunjukkan bahwa indikator yang berada pada kuadran ini, dianggap kurang penting oleh penyewa. Namun kinerja kualitas jasa yang diberikan pengelola asrama 
tergolong cukup. Faktor yang termasuk pada kuadran 2, antara lain: ruangan publik dan asrama terjaga kebersihannya, bangku dan meja pada ruang publik tertata rapi.

Kuadran 3, menunjukkan bahwa faktor yang berada pada kuadran ini dianggap kurang penting oleh penyewa (jasa yang diharapakan konsumen), dan kinerja kualitas layanan jasa (jasa yang dirasakan) yang diberikan oleh pengelola asrama juga dirasakan kurang.

Penelitian ini memiliki beberapa keterbatasan yaitu, pertama, pengukuran variabel kualitas layanan hanya berdasarkan dimensi tangibility, emphaty, reliability, responsiveness, dan assurance. Kedua, kemungkinan terjadinya kesenjangan persepsi antara kualitas layanan menurut penyewa yang seluruhnya adalah mahasiswa dengan peneliti. Untuk mendapatkan indikator kuallitas layanan yang sempurna baik, disarankan pada penelitian berikutnya untuk melakukan focus group discussion untuk memperkecil gap persepsi antara peneliti dan mahasiswa

\section{DAFTAR PUSTAKA}

Aritonang, R.L., Kepuasan Pelanggan, Gramedia, Jakarta, 2005

Bansal, Harvir, S., Shirley, F., Taylor, dan Yannik St. James, 2005, "Migrating to New Service Providers: Toward a Unifying Framework of Customers Switching Behaviors". Journal of The Academy of Marketing Science, Vol. 33, No.1.

Dimyati, M. 2002. "Analisis Kesenjangan Antara Harapan Dengan Persepsi Atas Kualitas Jasa Pendididkan Tinggi: Kasus di FE Universitas Jember." Surabaya: Jurnal Riset Ekonomi dan Manajemen,. Vol. 1. No. 1 September.

Fandy Tjiptono, 2001. Total Quality Manajemen. Edisi Revisi. Cetakan IV. Yogyakarta: Penerbit Andi.

Fandy Tjiptono, 2000. Perspektif Manajemen dan Pemasaran Konterporer. Edisi 1, Yogyakarta:Penerbit Andi.

Haryanto. J. \& Chairy, 2007, "Model Baru Dalam Migrasi Pelanggan”. Jurnal Ekonomi dan Bisnis Fakultas Ekonomika dan Bisnis UKSW, Vol. XIII No.1. 
Kaihatu, Stefanus T. 2008. “Analisa Kesenjangan Kualitas Pelayanan dan Kepuasan Konsumen Pengunjung Plaza Tunjungan Surabaya Jurnal Manajemen dan Kewirausahaan, Vol. 10, No.1, Maret 2008, 66-83.

Kotler Philip. 1997. Manajemen Pemasaran. Edisi IX (terjemahan), Jilid II. Jakarta:

Penerbit Erlangga Jakarta Cetakan XV.

Liza Agustina Maureen Nelloh, Carolina Chandra Purwanto Liem. 2011. Analisis Switching Intention Pengguna Jasa Layanan Rumah Kos Di Siwalankerto: Perspektif Kualitas Layanan dan Kepuasan Pelanggan. Jurnal Manajemen Pemasaran, Vol. 6, No.1 April 2011: 22-31. 1988. Managing Service: Marketing, Operation, and Human Resources. London: Prentice-Hall International, Inc.

Massie James D., 1998. Menciptakan KepuasanPelanggan Melalui Quality Function Deployment (QFD): Alternatif Meraih Keunggulan Operasional Perusahaan Dan Membangun Relatioship Marketing. Majalah Efisiensi. Fakultas Ekonomi Universitas Sam Ratulangi.

Parasuraman, A. Zeithaml, V.A., Berry L.L. 1988. "SERVQUAL: A Multiple-Item Scale for Measuring Consumer Perceptions of Service Quality". Journal of Retailing, Vol. 64, Spring.

Parasuraman, A. Zeithaml, V.A., Berry L.L. 1985. "A Conceptual Model of Service Quality and ItsImplications for Future Research". Journal of Marketing, Vol. 49, Fall.

Ramadania. 2002. "Kepercayaan dan Komiotmen Sebagai Perantara Kunci Relationship Marketing Dalam Membangun Loyalitas (Survey Pada Nasabah Bank Muamalat Indonesia Surabaya).” Jurnal Riset Ekonomi dan Manajemen, Vol.2 No. 1, Januari. Surabaya.

Supramono dan Haryanto, O.J., 2005, Desain Pro-posal Penelitian Studi Pemasaran. Penerbit Andi Yogyakarta. 